\title{
The Tannin-Degrading Species Streptococcus gallolyticus and Streptococcus caprinus Are Subjective Synonyms
}

\author{
LINDSAY I. SLY, ${ }^{1 *}$ MARIAN M. CAHILL, ${ }^{1}$ RO OSAWA, ${ }^{2}$ AND TOMOHIKO FUJISAWA ${ }^{2}$ \\ Centre for Bacterial Diversity and Identification, Department of Microbiology, The University of Queensland, Brisbane, \\ Queensland 4072, Australia, ${ }^{1}$ and Kanagawa Prefectual Public Health Laboratory, Asahi-ku, Yokohama, Japan ${ }^{2}$
}

\begin{abstract}
The tannin-degrading species Streptococcus gallolyticus and Streptococcus caprinus have been shown to be subjective synonyms on the basis of their levels of $16 \mathrm{~S}$ rRNA sequence similarity (98.3\%) and DNA-DNA homology $(>70 \%)$ and the phenotypes of their type strains. S. gallolyticus has nomenclatural priority according to Rule $24 b(2)$ of the International Code of Nomenclature of Bacteria.
\end{abstract}

Recently, two tannin-degrading Streptococcus species have been described. Osawa et al. isolated strains of streptococci capable of degrading tannin-protein complexes from the feces of various animals (11-15). These strains, which ferment mannitol, have conventionally been classified as Streptococcus bovis biotype I strains and have been distinguished from biotype II strains, which do not ferment mannitol. Farrow et al. (5) demonstrated on the basis of DNA relatedness data that biotype I strains were genotypically homogeneous and distinct from biotype II strains, which include the type strains of Streptococcus bovis and Streptococcus equinus. Similar observations were made by Knight and Shlaes (9) and Coykendall and Gustafson (3) for isolates of clinical origin. Osawa and Walsh (16) demonstrated that many $S$. bovis biotype I strains produce an enzyme, tannase, which hydrolyzes tannins to release gallic acid, which is then decarboxylated to pyrogallol by gallate decarboxylase (17). Subsequently, it was shown that all strains of $S$. bovis that exhibited gallate decarboxylase activity belonged to a single DNA homology group described as Streptococcus gallolyticus (13). S. gallolyticus contains strains isolated from diverse habitats, including the feces of koalas, kangaroos, brushtail possums, ringtail possums, cows, horses, pigs, dogs, and guinea pigs, as well as animals with bovine mastitis, human clinical sources, and the sheep rumen.

Concurrently with our studies, Brooker et al. (2) described a novel tannin-resistant species, Streptococcus caprinus, which was isolated from the rumen of a feral goat in Australia. The three strains studied were shown to form a coherent DNA homology group distinct from $S$. bovis and to be distinct from $S$. equinus and $S$. bovis on the basis of rRNA sequence similarity and phenotype data.

In order to determine the taxonomic relationship between $S$. gallolyticus and $S$. caprinus, we compared the type strains by studying their rRNA sequence similarity, DNA-DNA homologies, and phenotypes, including their tannase and gallate decarboxylase activities, which had not been determined previously for $S$. caprinus.

Extraction of genomic DNA and amplification of the $16 \mathrm{~S}$ rRNA gene were performed as described by Dorsch and Stackebrandt (4). The PCR products were purified by using a MicroSpin type S-300 purification column (Pharmacia Biotech) as described by the manufacturer. A PRISM Ready Reaction DyeDeoxy terminator cycle sequencing kit (Applied Biosystems, Foster City, Calif.) was used to directly sequence the PCR products with an Applied Biosystems model 373A auto-

\footnotetext{
* Corresponding author. Phone: 6173365 2396. Fax: + 6173365 1566. E-mail: sly@biosci.uq.oz.au.
}

matic DNA sequencer. The $16 \mathrm{~S}$ ribosomal DNA (rDNA) sequence obtained was aligned manually with the sequence of $S$. caprinus $2.3^{\mathrm{T}}\left(=\mathrm{ACM} 3969^{\mathrm{T}}\right)$ (accession no. Y10868) and representative bacterial 16S rDNA sequences obtained from the Ribosomal Database Project (10). Positions at which length and sequence variations made alignment uncertain were omitted. Pairwise levels of evolutionary similarity and distances (8) were computed with the DNADIST program in the PHYLIP, version 3.4, software package (6). A phylogenetic tree (data not shown) that was constructed by using the neighbor-joining method of Saitou and Nei (18) showed that $S$. gallolyticus and $S$. caprinus clustered together in a phylogenetic group together with $S$. bovis, $S$. equinus, and Streptococcus alactolyticus. The latter three species were also previously shown to form a coherent phylogenetic group in an analysis that included 31 species of the genus Streptococcus (1). The rRNA sequences of $S$. gallolyticus and $S$. caprinus exhibited $98.3 \%$ sequence similarity in an analysis of 1,266 nucleotide positions.

DNA homology experiments with the type strains of $S$. gallolyticus, $S$. caprinus, and $S$. equinus were performed by using the S1 nuclease method as previously described (13). Table 1 shows that the levels of homology between the DNAs of $S$. gallolyticus and S. caprinus are 67 to $74 \%$. Levels of DNADNA homology of $>70 \%$ indicate that strains belong to the same species (20). The results also confirmed that the type strains of $S$. gallolyticus and $S$. caprinus are genotypically distinct from $S$. equinus.

$S$. caprinus ACM $3969^{\mathrm{T}}$ was shown to have the tannase activity and the gallate decarboxylase activity characteristic of S. gallolyticus (13) by the methods of Osawa and Walsh (16) and Osawa et al. (17), respectively. The biochemical characteristics of the type strains of $S$. gallolyticus and $S$. caprinus were determined by the API 20 STREP strip method (API System, Montalieu, Vercieu, France). The results showed that both strains were positive for the Voges-Proskauer reaction, esculin hydrolysis, leucine arylamidase activity, and acid production from mannitol, lactose, trehalose, starch, and glycogen. The strains were negative for hippurate hydrolysis, pyrrolidonylarylamidase, $\beta$-glucuronidase, $\beta$-galactosidase, alkaline phosphatase, and arginine dihydrolase activities, and acid production from ribose, L-arabinose, sorbitol, and inulin. Neither strain produced beta-hemolysis of sheep blood cells. The two type strains differed in two characteristics. The $S$. gallolyticus strain was positive for $\alpha$-galactosidase activity and acid production from raffinose, while the $S$. caprinus strain was negative for these characteristics. Brooker et al. (2) found that $S$. caprinus utilized raffinose as a growth substrate.

Overall, the phylogenetic, genotypic, and phenotypic results 
TABLE 1. Levels of DNA homology among the strains tested

\begin{tabular}{lcc}
\hline \multirow{2}{*}{ Strain } & \multicolumn{2}{c}{$\begin{array}{c}\text { Homology with }{ }^{3} \mathrm{H} \text {-labeled } \\
\text { DNA from: }\end{array}$} \\
\cline { 2 - 3 } & $\begin{array}{l}\text { S. gallolyticus } \\
\text { ACM 3611 }\end{array}$ & $\begin{array}{r}\text { S. caprinus } \\
\text { ACM } 3969^{\mathrm{T}}\end{array}$ \\
\hline S. gallolyticus ACM 3611 & 100 & 74 \\
S. caprinus ACM 3969 & 67 & 100 \\
S. equinus ACM 3541 & 20 & 19 \\
\hline
\end{tabular}

indicate that $S$. gallolyticus ACM $3611^{\mathrm{T}}$ and $S$. caprinus ACM $3969^{\mathrm{T}}$ belong to the same species. Both species were described outside the International Journal of Systematic Bacteriology, and the names were validated in 1996 on the same validation list (7). This validation list indicates that $S$. gallolyticus has higher priority than $S$. caprinus based on the order of receipt of their effective publications for validation. Under Rule $24 \mathrm{~b}(2)$ of the International Code of Nomenclature of Bacteria (19), S. gallolyticus therefore has nomenclatural priority.

Nucleotide sequence accession number. The nucleotide sequence of $S$. gallolyticus ACM $3611^{\mathrm{T}}$ determined in this study has been deposited in the EMBL Data Library (Cambridge, United Kingdom) under accession no. X94337.

We thank Linda Blackall for providing the 16S rDNA sequence of $S$. caprinus prior to its deposition in the EMBL Data Library.

\section{REFERENCES}

1. Bentley, R. W., J. A. Leigh, and M. D. Collins. 1991. Intrageneric structure of Streptococcus based on comparative analysis of small-subunit rRNA sequences. Int. J. Syst. Bacteriol. 41:487-494.

2. Brooker, J. D., L. A. O'Donovan, I. Skene, K. Clarke, L. Blackall, and P. Muslera. 1994. Streptococcus caprinus sp. nov., a tannin-resistant ruminal bacterium from feral goats. Lett. Appl. Microbiol. 18:313-318.

3. Coykendall, A. L., and K. B. Gustafson. 1985. Deoxyribonucleic acid hybridizations among strains of Streptococcus salivarius and Streptococcus bovis. Int. J. Syst. Bacteriol. 35:274-280.

4. Dorsch, M., and E. Stackebrandt. 1992. Some modifications in the procedure of direct sequencing of PCR amplified 16S rDNA. J. Microbiol. Methods 16:271-279

5. Farrow, J. A. E., J. Kruze, B. A. Phillips, A. J. Bramley, and M. Collins. 1984 Taxonomic studies on Streptococcus bovis and Streptococcus equinus: description of Streptococcus alactolyticus sp. nov. and Streptococcus saccharolyticus sp. nov. Syst. Appl. Microbiol. 5:467-482.

6. Felsenstein, J. 1991. PHYLIP, version 3.4. University of Washington, Seattle.

7. International Journal of Systematic Bacteriology. 1996. Validation of the publication of new names and new combinations previously effectively published outside the IJSB. List no. 56. Int. J. Syst. Bacteriol. 46:362-363.

8. Jukes, T. H., and C. R. Cantor. 1969. Evolution of protein molecules, p 21-132. In H. N. Munro (ed.), Mammalian protein metabolism. Academic Press, New York, N.Y.

9. Knight, R. G., and D. M. Shlaes. 1985. Physiological characteristics and deoxyribonucleic acid relatedness of human isolates of Streptococcus bovis and Streptococcus bovis (var.) Int. J. Syst. Bacteriol. 35:357-361.

10. Maidak, B. L., N. Larsen, J. McCaughey, R. Overbeeck, G. J. Olsen, K. Fogel, J. Blandy, and C. R. Woese. 1994. The Ribosomal Database Project. Nucleic Acids Res. 22:3483-3487.

11. Osawa, R. 1990. Formation of a clear zone on tannin-treated brain heart infusion agar by a Streptococcus sp. isolated from feces of koalas. Appl. Environ. Microbiol. 56:829-831.

12. Osawa, R. 1991. Occurrence of tannin-protein complex degrading Streptococcus bovis sp. in feces of koalas. J. Wildl. Manage. 55:623-627.

13. Osawa, R., T. Fujisawa, and L. I. Sly. 1995. Streptococcus gallolyticus sp. nov.; gallate degrading organisms formerly assigned to Streptococcus bovis. Syst. Appl. Microbiol. 18:74-78.

14. Osawa, R., and L. I. Sly. 1991. Isolation and phenotypic characterization of $\mathrm{CO}_{2}$-requiring strains of Streptococcus bovis from koalas. Appl. Environ. Microbiol. 57:3037-3039.

15. Osawa, R., and L. I. Sly. 1992. Occurrence of tannin-protein complex degrading Streptococcus sp. in various animals. Syst. Appl. Microbiol. 15:144 147.

16. Osawa, R., and T. P. Walsh. 1993. A visual reading method for detection of bacterial tannase. Appl. Environ. Microbiol. 59:1251-1252.

17. Osawa, R., T. P. Walsh, and S. J. Cork. 1993. Metabolism of tannin-protein complex by facultative anaerobic bacteria isolated from koala feces. Biodegradation 4:91-99.

18. Saitou, N., and M. Nei. 1987. The neighbor-joining method: a new method for reconstructing phylogenetic trees. Mol. Biol. Evol. 4:406-425

19. Sneath, P. H. A. 1992. International code of nomenclature of bacteria: bacteriological code, 1990 revision. American Society for Microbiology, Washington, D.C.

20. Wayne, L. G., D. J. Brenner, R. R. Colwell, P. A. D. Grimont, O. Kandler, M. I. Krichevsky, L. H. Moore, W. E. C. Moore, R. G. E. Murray, E Stackebrandt, M. P. Starr, and H. G. Trüper. 1987. Report of the Ad Hoc Committee on Reconciliation of Approaches to Bacterial Systematics. Int. J. Syst. Bacteriol. 37:463-464. 